\title{
THE LOGIC OF BINCAR-BONOM AND STRUCTURALISM ANALYSIS ON ROOM ARRANGEMENT OF DWELLING IN MANDAILING
}

\author{
Cut Nuraini $^{1^{*}}$, Hibnul Walid ${ }^{2}$, Meyga Fitri Handayani ${ }^{3}$ \\ 1,2,3 Department of Architecture, Institute Technology of Medan, \\ Gedung Arca St. No.52 North Sumatera, INDONESIA \\ *Corresponding author; Email: cnuraini@itm.ac.id
}

\begin{abstract}
The structure on an idea of Singengu ancestor about Datu (Creator) which is gives tondi (spirit/soul) through direction of sun movement has established the logic of Bincar (sunrising direction) and Bonom (sunsetting direction). The logic of Bincar-Bonom with the axis point has been manifests in the form of myths about relationships between Datu (Creator/God), King (Datu's agent in the world) and the ancestors which also form the structure of abstract space namely Bincar and Bonom. The structure of abstract space namely Bincar-Bonom in the next steps has transformed concretely on architectural phenomena as a place on room arrangement. Bincar-Bonom in the context of structural concept is transformed in to room arrangement phenomenon concretely which has arrange the setting of bedroom for parent in the direction of Bonom and bedroom for son in the direction of Bincar with family room in the midle of it as axis point.
\end{abstract}

Keywords: Bincar-Bonom; Datu; Place; Space; Structuralism.

\section{INTRODUCTION}

Research about dwelling of a certain group of people in Indonesia is still very interesting to continue to do cause of the unique of its local values. There is a research which revealed evolution processes of dwelling culture and to compare the traditional spatial forms and the transformed ones, and also to emphasize the former attitude and to propose a sustainable strategy for developing the dwelling type by respecting and adopting the traditional culture and historic apologue (Wicaksono et al, 2016). In the other case, the phenomenon of a dwelling should be a manifestation of the dynamic roles of male and female members of the house and the circular arrangement of the space around the fireplace at the centre of the house follows the dynamic of gender duality. Its fact shows that the phenomenon of a dwelling was unique and full of different values (Nurdiah et al, 2015).

Dwelling as an architectural phenomenon not only related to the space of activity but also by the model of the inhabitants thought. Ahimsa (2014) explains that basically, an architectural phenomenon is the result of a symbolic interaction process for many years and eventually manifests itself in the form of symbols who always interpreted by the owner, the maker and also by society or other cultural advocates. Then Ahimsa (2014) reveals that the phenomenon is also like a sentence which is composed of a number from elements in such a way that has certain messages and have a meaning. The structural analysis of the architectural phenomena aims to reveal the elements that make up the phenomenon, its syntagmatic and paradigmatic circuits, its phenomenon structure and its transformational relation to other cultural phenomenon, either from the same culture or from different cultures (Ahimsa, 2014).

The structuralist view has a number of basic assumptions and models that serve as guidelines for anthropologists in general and other experts in particular such as architects in understanding, analyzing and explaining sociocultural phenomena. These assumptions are relatively new to most scientists in Indonesia, so it is not so easy to understand them. Structuralism departs from a number of basic assumptions about people, behavior and behavior out put (Ahimsa, 2014).

A house, or housing, and or settlement, as well as a sentence, also consists of a number of elements. These elements are not scattered without reference, but are arranged in such a way that it forms an architectural order with certain features and patterns or a landscape with a particular pattern. As a researcher, we can parse or analyze the architecture or landscape arrangement, so that we can know what the elements of its formation are. But, the more important is to reveal the structure or circuit patterns of the elements.

In human life, an architectural phenomenon, be it buildings, neighborhoods and or settlements with all the patterns of space is like a sentence. The phenomenon is awakened from a number of elements that are awakened in such a way as to indicate a particular spatial pattern or order that conveys certain messages (Ahimsa, 2014). 
In line with the above explanation, it can be assumed that the layout of room arrangement of Mandailing community dwelling in two villages of Huta Adat (Singengu and Habincaran) can be likened to a sentence that has a syntagmatic and paradigmatic sequence like a language.

The background that has been described formulate the problem, what kind of room arrangement structure of Mandailing residence in Singengu and Habincaran villages? The purpose of structural analysis conducted on the room arrangement of Mandailing tribal house as an architectural phenomenon is to reveal the structure of human's creation in two villages of Huta Adat (Singengu and Habincaran) in the room arrangement of houses that are not always realized "grammar" by the people who built it. The people of Singengu and Habincaran villages in building their houses they can not always explain the architectural details of the buildings they build, but can be extracted from the thinking of the villagers themselves.

\section{BASIC ASSUMTIONS OF STRUCTURALISM}

In structuralists, humans are seen as animal symbolicum, animals that are able to create and use symbols or to communicate, adapt and respond to their environment. Language is the most important symbolic system in human's life. Language is a symbolic device that enables human beings to communicate with other humans, so that people's lives and culture are born. Language is the basis for society and culture (Ahimsa, 2014).

Ahimsa (2014) also revealed some experts argue that symbols are those that represent something. But, a symbol can't represent something if there is no human. The people is the maker who makes something (symbol) so that it represents something. Some other experts say that symbols are all things that are meaningful, but if a symbol or symbol has a meaning, then of course the meaning will be attached to the symbol. In fact, this meaning is not attached in the symbol. Meaning is given by the people. Therefore, some experts argue that the symbol is anything that is interpreted. This definition implicitly explains that the meaning of symbols are not present in the symbol itself, but it is given by humans (White, 1963; in Ahimsa, 2014).

Man is capable of giving meaning. A symbol has two aspects such as: (a) the miners (symbolic) and aspect (b) symbolic (which symbolized) or the symbolic aspect and its meaning. These two aspects are interconnected but these relationships are arbitrary. Saussure (1970 in Ahimsa, 2014) calls the symbol is a sign. There is no intrinsic connection between the miner and its symbol, between the symbol and its meaning because man who created the relationship. The creation or laying of the relation between the symbol and its meaning is what is said by "meaning". Understanding is basically to define or setrelation "re-presentational" between a symbol with a meaning, that is idea or thougt (Ahimsa, 2014).

Another researcher (Hawkes, 2003) revealed that structuralism is fundamentally a way of thinking about the world which is predominantly concerned with the perception and description of structures. In fact, every perceiver's method of perceiving can be shown to contain an inherent bias which affects what is perceived to a significant degree.

\section{STRUCTURE, TRANSFORMATION, AND AWARENESS}

The structure according to Lévi-Strauss is a model made by anthropologists to understand or explain the symptoms or cultural events studied. In structural analysis, 'structure' is divided into two types: 'surface structure' and 'deep structure'. Surface structure is the arrangement of elements that appear on the outside, but can be known through the analysis and comparison of various external structures that have been found. This inner structure is more precise referred to as a "model" to understand the phenomenon under study (Ahimsa, 2014).

Ahimsa (2014) explains that transformation in the context of structuralism has a different meaning. In general, transformation means "change" while in the context of structuralism means "transition". This means that in the transformation that occursis actually only a change in the surface level, while at a deeper level again, the change does not occur or not directly. In the other words, it can be said that in a transformation, changes that occur only change in "skin" or "container", while the contents in the container is not changed. Transformation can not be equated with change because in change there is a sense of the process of changing something to something else in a certain space and time. 'Change' is just the translation of change. This is different with the transformation which refers to the change of things but "not through a process" or the process is not considered essentialor the process is at a deeper or more abstract level.

According to Ahimsa (2014) the transformation in the structuralist paradigm which means transfers is a structural or transitional transformation at the level of structure, but only on the surface structure. This structure is not always aware of its existence by the user, because the user is not an expert who can understand a particular structure. People who can understand the structure are experts, in this case are 
researchers. So, the existence of a structure in the sense of transfiguration is usually not recognized by the user. In other words, it can be said that the structure is at the unconscious level.

\section{ARCHITECTURE AS LANGUAGE: STRUCTURALISM ON ARCHITECTURE}

Lakawa (2015) described that language is a form of verbal communication and architecture is a form of non-verbal communication. As a form of non-verbal communication, an architect should understand well how to communicate in this non-verbal language, so that the purpose and objectives of the building can be achieved (Lawson, 2001 in Lakawa, 2015). Lawson (2001 in Lakawa) explained that space as part of architecture is an important aspect that is very basic and represents general flow of communication. Other researcher described that as in all types of communication, an indispensable aspect is the signification. It is fundamental (Marota et al, 2017). So, a settlement including residential or a dwelling can also have a pattern as well as a language with spesific sign. The dwelling pattern of a particular community can also be known and shoul be read as we read a description of the story by its sign. Lazutina et al (2016) also explained that architecture as a sign system begins to be treated by analogy with the language system. Structuralist dimensions of language are applied to the allocation of syntagmatic and paradigmatic sense levels. The historical and cultural significance is certainly important, it is, by the way, the basis for conferring an architectural monument status to the building, but it is no less important how architectural work determines people`s behavior. As Lazutina et al (2016) described above, so, the out put of people`s behaviour as called structure or model is important to revealed. The difference is the language in architecture with spesific sign can make and produce the space and place, even in structuralism, language just showed the structure of though model. .

According to Hillier (1984 in Nuraini, 2017) space is always related to humans realistic and its life as called space-society relations. The architecture always discuss about space, so in this term, the architecture should be understood about not only physical aspect but also non-physical. Its has two structures, namely 1) space as something visible or tangible and 2) superficial as something invisible or the deep structure. Architecture according to Hillier in Nuraini (2017) loaded with human content that formed space because there is a relation with the artifacts thereby evolves toward the spatial and cultural concept. Human organizes spatial milieu in order to produce construction which is called spatial culture. Spatial order is a way or order of a certain space that reveals the artificial relation order based on the principle of the social order. In this concept there is a very close mutual relationship between the spatial artifacts as spatial culture with the social order or relationship that inhabits or uses the artifacts in its living space in the society. At a certain moment, the spatial is influenced by the social order and at the other moments the social order is influenced by the physical order of the space. Therefore, Hillier in Nuraini (2017) revealed that the architecture of the settlement (including residential or home) is a sociospatial artifact.

Based on the description aboved, it can be stated that structuralism in architecture can be compared with structuralism especially in the context of activities or activities that make or produce the space. The difference is, architecture emphasizes the space while the structuralist emphasis is on the structure as a model of thought. One of another important aspect that distinguishes between structuralist and architecture is the existence of space values. Adiwijaya (2011) described that only using the language analysis is not enough to interpret the phenomenon especially the phenomenon of architecture in society.

\section{METHODOLOGY}

This research uses structuralism paradigm which ontologically explores phenomenon structure by looking at the transformation on the deep and the superficial structure. Structuralism is commonly used by anthropologists in analyzing a culture and / or cultural phenomena. This paradigm departs from the assumption that culture is essentially symbolic devices, because the creator or its supporters are humans who are essentially animal symbolicum (Ahimsa, 2014). Its ontologically explores the structure of a phenomenon by looking at the transformation. The attempt to explore the structure of a phenomenon is epistemologically done through two analyzes: 1) a symbolic analysis to uncover the meaning of various 'conscious' and; 2) a semiotic analysis to reveal the meaning/logic behind the 'unconscious' objects to be seen in the sequence of structural transformations based on the model of human thought. In axiological structuralism produces knowledge of how to extract the structure or the model of thought behind the phenomenon. Structuralism analysis on architecture in the end of research has shown the interrelationship between the deep and the superficial structure (Hillier, 1984 in Nuraini, 2017). The result of analysis is then translated in the form of space transformation in architectural context which is focus on three key factors namely activities, space and values. These 
combine methods are needed to better demonstrate the architectural value of the case studies as Adiwijaya (2011) explained that merely picking up the aspect of language analysis to apply to the design, ie participate and regard it as a sign that refers to meaning (signifier \& signified) without understanding the meaning, the foundation and theoretical construct of semiology/structuralism itself is already a symptom intellectual deficit. Thus, the findings of the structure of thought were analyzed by using local theory which is found on previous research findings.

\section{RESULTS and DISCUSSION}

\section{Singengu Village in Mandailing Julu, Kotanopan District, Mandailing Natal Regency, North Sumatera}

Singengu village is the oldest village in Mandailing Julu area which is in the past became the center of the reign of kings surnamed Lubis, and was the first place on the banks of the river to be settled by the ancestors of the Singengu people, who previously settled in the mountains. Habincaran Village is Singengu's 'child village' with the status of the youngest huta adat in the Mandailing Julu Area which has the same customary structure as its parent village, Singengu. The two villages are strongly linked by custom, because Habincaran village is developed by the descendants of the king in Singengu village.

The ancestors of the Mandailing people have always believed that banua, the earth or real word where human lives with everything in it is a creation of Datu (the Creator). Creator gives life and tondi (spirit) to all of people or human through the direction of movement of rising and setting sun, or bincarbonom (Nuraini, 2014a; Nuraini 2014b). This belief is transformed by the Singengu and Habincaran people in the form of bincar-bonom logic embodied in the bagas (house) layout. The illustration of the structure of thought can be seen in figure 1 .

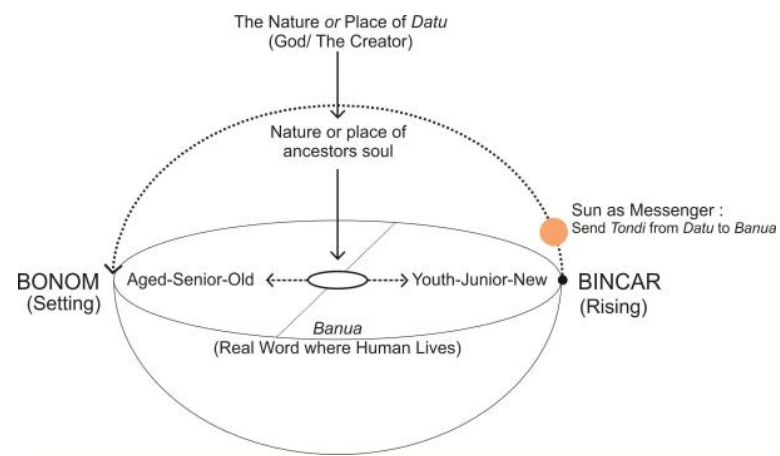

Fig. 1. The structure of ancestral mindset of the Mandailing people in Singengu and Habincaran villages on vertical relationship
The abstract structure of the Mandailing ancestors' thought of Datu (the Creator and Mataniari (sun) on the logical level whose manifestation is indicated by the spinning relations, the axis points and bonom further manifest in the mythical order by the existence of creator relation, ancestor and head of household as owner a bagas (dwelling/home) as shown in figure 2. This relation also shows three elements, namely bincar, tonga and bonom. The structure of thought about bincar-bonom in the form of a relation between the place for the head of the household as a senior (the parent's bedroom) and a place for the boy-male heir as junior (child's bedroom) with tonga as an axist point. The structure of BincarBonom mindset that manifests in the concrete level of the order of personal space can be seen in figure 3 .

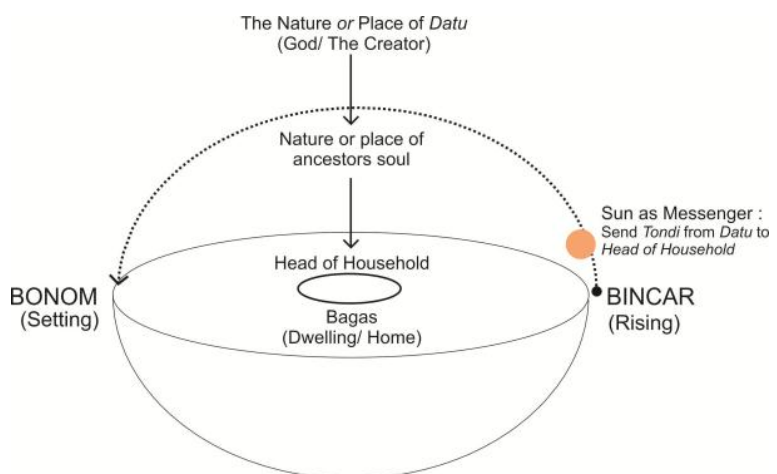

Fig. 2. The structure of mindset that manifests on the level of the myth of Datu (creator/God)-Ancestor-Head Household

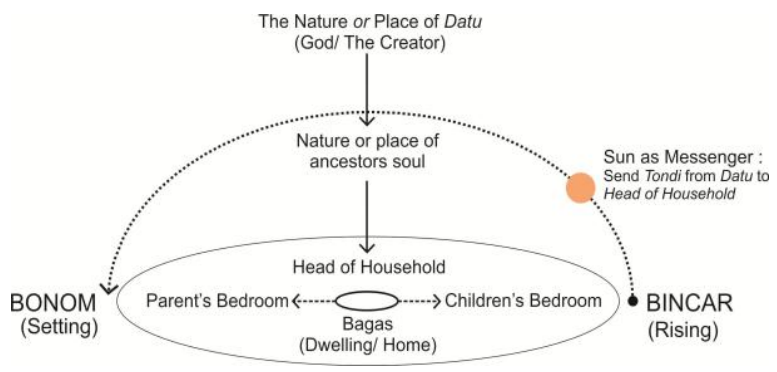

Fig. 3. The structure of Bincar-Bonom mindset that manifests in the concrete level of the order of personal space

\section{Bincar-Bonom as the basis of spatial arrangement}

According to Nuraini and Thamrin (2017) bincar-bonom is a local theory of Singengu village settlement that has become a principle guidelines in arranging a living space in the residential areas. Bincar, which is means sunrise and bonom, which is means sunset are not merely term to indicate the directions of sunrise and sunset but have becomes the base of forming singengu village spatial plan which is empirically translated in the form of placement, 
setting or location of physical elements of settlements in the three spatial scale in such away. Thus, it is always on the bincar-bonom axis with an emphasis on three important relations, i.e. the relation between people, present day people to the ancestors, and all people to the Creator. As a local theory, bincar is identical with youth, junior and new, while bonom is identical to the aged, senior and old (Nuraini and Thamrin, 2017). The theory of Bincar-Bonom illustrated in figure 4 .
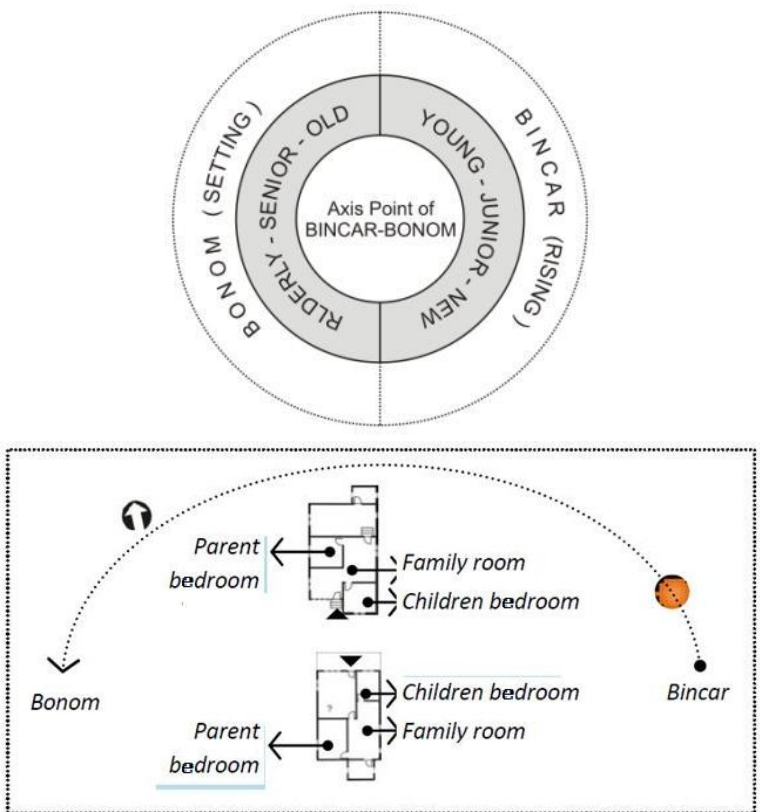

Fig. 4. The theory of Bincar-Bonom and the aplication of its on bedroom arrangement for parents and son in Singengu Village. (Sources: Nuraini et al, 2014a in Nuraini and Thamrin, 2017)

\section{Room Arrangement Concepts}

Nuraini (2017) revealed the eight heirloom houses in other huta, namely Hutagodang village and demonstrate that the position of tonga as the axis has determined the location of other spaces around them in terms of the nature and the value space. The private room for elderly that is pantar bilik-1 (bed room for parent) is placed in the western of pantar tonga (living room), while the private space for the childis (youngest son as a heir) in the east direction of the living room. This shows the consistency of arrangement of the spaces with the center space as the axis.

According to Nuraini (2017) from the beginning, the ancestors of Mandailing people realized that this world had been created by Datu, so there was an understanding of the world of Datu (creator) and the human world. The first man created by Datu (the creator) is an ancestor whose spirit is very closed to
Datu. Continuous contact with the ancestors is believed to bring magnificent life so that the ancestors as the 'base' of the current generation should be in respected and followed (Nuraini, 2017). The development of other spaces in a dwelling serves as the midpoint of the imaginary line connecting human life in the micro cosmos with the Datu (creator) in the macro cosmos through the axis of Bincar-Bonom as shows on figure 5 (Nuraini, 2017).

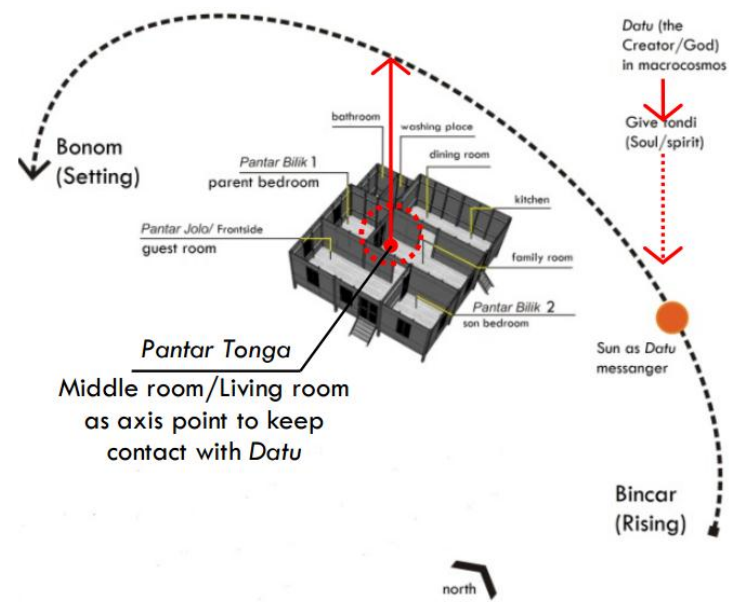

Fig. 5. Imaginary line connecting human life in the microcosmos with the Datu (creator/God) in the macro-cosmos through the axis of Bincar-Bonom. (Sources: Nuraini, 2017)

The bincar-point axis-bonom relationships firstly were only abstract and in the logic of the mind (the Singengu people's mind) were transformed concretely at the level of architectural phenomena (house spatial) and socio-culture. The bonom-axiscentered transformation of the home and space settings can be seen in the relationship between the child's bedroom, the living room and the parent's bedroom. The illustrations can be seen in figure 6 and figure 7 .

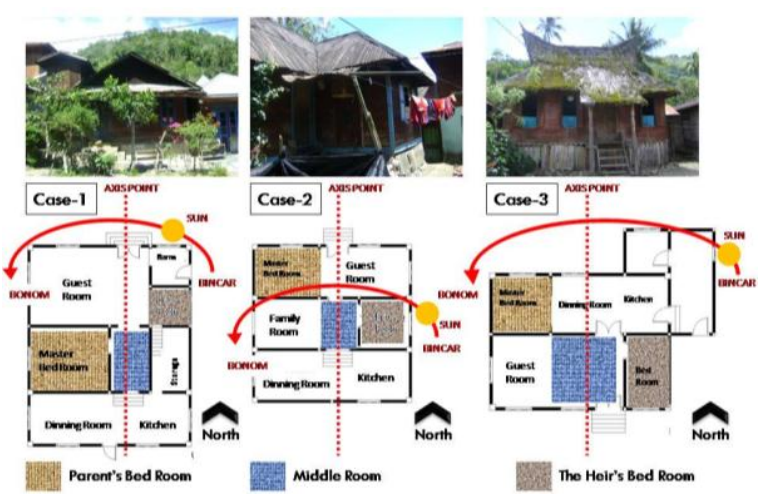

Fig. 6. The structure of bincar-bonom mindset that manifests at the concrete level in three cases of residential sample of Habincaran village 


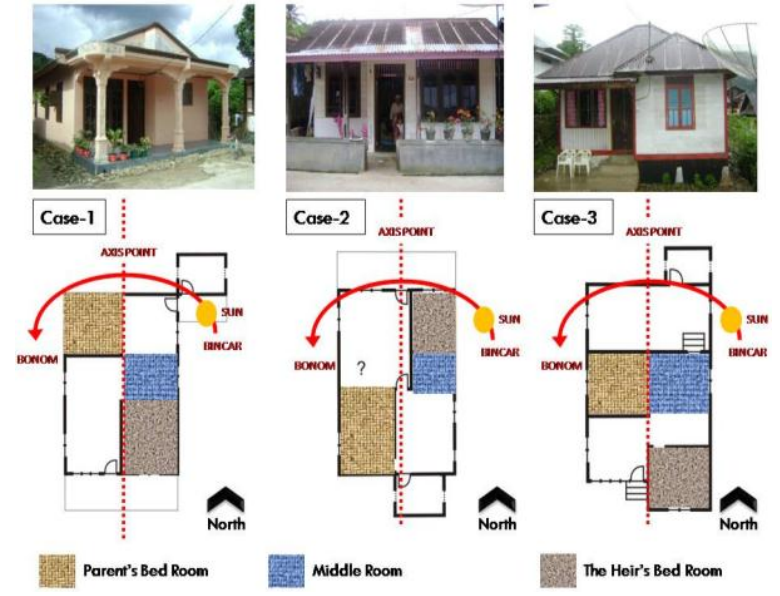

Fig. 7. The structure of bincar-bonom mindset that manifests at the concrete level in three sample residential of Singengu vilages.

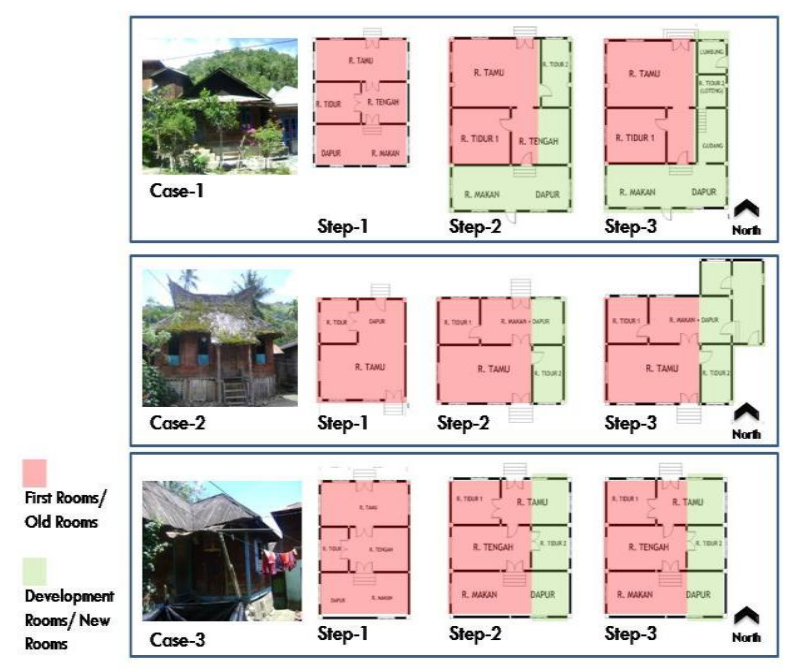

Fig. 8. The structure of the bincar-bonom mindset manifests in the process of building three residential samples in Habincaran village

The transformation not only occurs in the arrangement of personal space (bedrooms), but also on the process of overall home development. Spaces develop according to the logic of the bincar-bonom, which is places the old spaces in order to always be in the bonom area, whereas the new spaces, are developed toward the bincar, as shown in figures 8 and 9.

Bagas as a dwelling of Mandailing people in mountainous area always begins by a simple bagas (dwelling) which is consist of four room, namely pantar bilik (bedroom), pantar tonga (family room), pantar jolo (guest room), and pantar pudi (kitchen). The simple bagas are the first home for newly married couples. At the time of the birth of the child, all the space is extended to the bincar area, including the tangga jolo (front staircase) as access to entry into the a simple bagas. At a step two, the second pantar bilik (bedroom) was built when the children are getting older by using some area of pantar jolo (guest room). At this step, the pantar pudi (kitchen) was expanded towards the backside area. Step one to step three, a simple bagas is still in a pillar house. In the fourth step, the pantar pudi (kitchen) located in the backside area was built directly on the ground, so a pillar house is only on the part of the pantar bilik (bedroom), pantar tonga (middle room/family room) and pantar jolo (guest room). Access to the pantar pudi (kitchen) was built up the staircase (stair in backside). At this step the bathroom was built in backside but also in bincar area. Staircase (stair in backside) and bathroom were also built in the direction of bincar. The most contrass changes occur in the final stages. In the final stages of development of a bagas, there is a difference of each bagas (home/dwelling), but the difference has the same direction tendency: the direction of the bincar as a reference.

Bincar-bonom at home scale, for example should be seen in spatial pattern in which always put new function in the direction of bincar. A simple bagas (dwelling/home) will usually grow larger because of the marriage of a child. Boys as heirs, if he was married, so he will move and occupy a new space/room in the opposite direction of the parent room that remains in the direction of the bonom, as illustrated figure 10. The new function can also be a kitchen extension, the addition of a side terrace and a bathroom. The room which is has a worth functions (dirty) like the bathroom, still placed in the area of the back side area but always in the direction of bincar (rising).

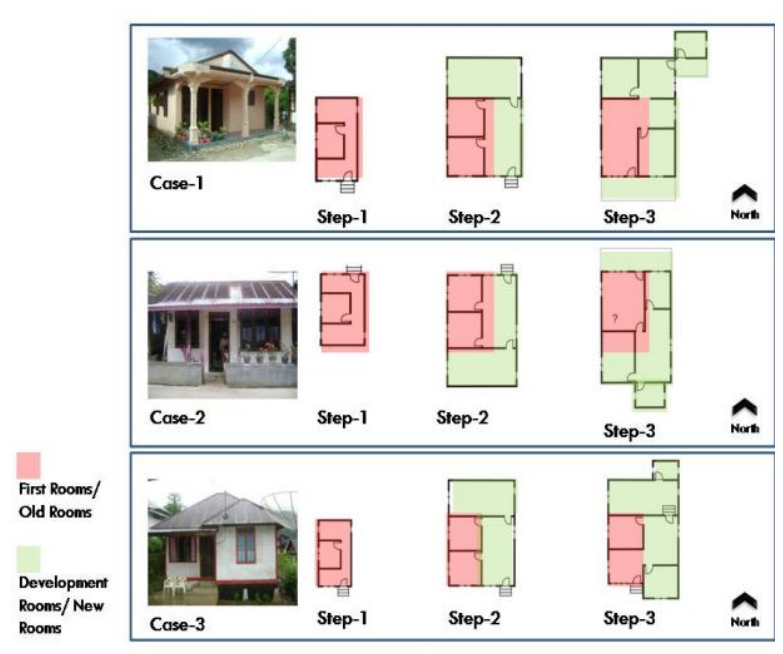

Fig. 9. The structure of the bincar-bonom mindset that manifests in the process of building three residential samples in Singengu village 


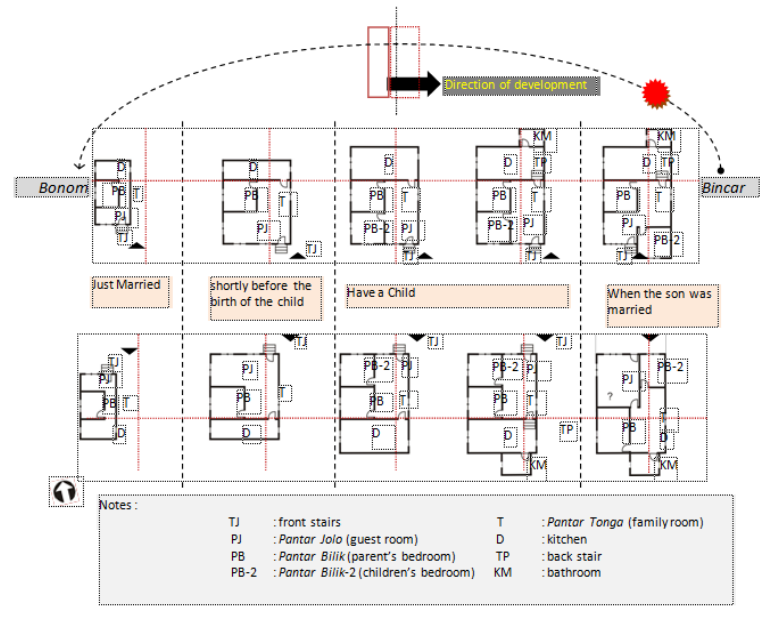

Fig. 10. The development of a simple bagas (houses) to be a bigger one of new Bagas which is always develop new spaces toward the bincar and the old space in the direction of bonom.

Table 1. Analysis of structuralism on the spatial arrangement in the dwelling

\begin{tabular}{|c|c|c|}
\hline CHARACTER & LEVEL & MANIFEST \\
\hline$\overline{\text { Abstract }}$ & Logic & $\begin{array}{l}\text { Datu (The creator/God) gives } \\
\text { tondi (soul/life) trough the } \\
\text { direction of sun movements : } \\
\text { Bincar-axis point-Bonom as } \\
\text { vertical relation (macrocosmos) } \\
\text { MANIFEST }\end{array}$ \\
\hline Abstract concrete & Myth & $\begin{array}{l}\text { Creator-King-Anchestor } \\
\text { (Bincar - Tonga - Bonom) } \\
\text { Creator-Anchestor - Head of } \\
\text { Household as vertical relation } \\
\text { (microcosmos) } \\
\text { TRANSFORMATED }\end{array}$ \\
\hline Concrete & $\begin{array}{l}\text { Architecture } \\
\text { Phenomenon } \\
\text { (order of room } \\
\text { arrangement) }\end{array}$ & $\begin{array}{l}\text { Private room setting : } \\
\text { Child's bedroom - living room- } \\
\text { parent's bedroom as horizontal } \\
\text { relation (microcosmos) } \\
\text { TRANSFORMATED } \\
\text { Service room setting : } \\
\text { Bathroom - dining room - } \\
\text { Kitchen } \\
\text { TRANSFORMATED } \\
\text { Front room/guest - living room- } \\
\text { back room }\end{array}$ \\
\hline
\end{tabular}

(Source: Analysis, 2018)

Structural analysis performed on the phenomenon of private space (bedroom) in residential in two villages (Singengu and Habincaran) as the result of dialogue between structuralism and phenomenology in the context of ontology, epistemology and axiology can be seen in table 1. Structural analysis conducted by researchers inspired by structural analysis of Umar Khayam tale conducted by Ahimsa (Ahimsa, 2001: 305).

The structure of the interior arrangement in the residential area of the Singengu and Habincaran villages is one of the forms of a deeper structure, the Bincar-Bonom structure. Bincar-Bonom is a deep structure that never changes and always used as a guide in forming spaces in the residential. BincarBonom has been transformed concretely in the order of space in the residential area of Singengu and Habincaran villages.

\section{CONCLUSION}

Structural analyzes that have been done on room arrangement in the Singengu and Habincaran village shows that the physical structure of space is a manifestation of one form of a deeper structure or deep structure that never changes. The structure of space as creation humans is similar to the structure of language that can pass through transformation in the context of "transfiguration" at the surface, but at a deeper level, the structure is unchanged. In line with the theory of spatial structure, local theory asserts and provides empirical evidence that the structure of the Singengu's thought of Datu (the Creator) who gives tondi (spirit/soul) through the direction of the mataniari movement (the sun) has formed the logic of Bincar (rising) - axis point - bonom (immersed). The Bincar-Bonom logic with its axis points manifests in the mythical form of the relation between Datu (the Creator), the king (the representative of Creator in the world) and the ancestor (to Creator) also forming the abstract structure of Bincar (rising) - axis point bonom (immersed). Abstract space structure Bincar (rising) -axis point- bonom (immersed) then transformed concretely in the form of architectural phenomenon (interior) residential Mandailing community in Singengu and Habincaran villages.

Bincar-Bonom as the transcendental awareness existing in the minds of the Singengu people continues to be brought and becomes an eternal model in shaping the layout of room arranegement on bagas (dwelling/home). Bancar-Bonom as an abstract structure or model of thought has become the basis for the formation of room arrangement and transformed or 'transfigured' into concrete and manifest physical spaces in the form of room arrangement.

Structural analyzes that have been done on the spatial layout in Singengu and Habincaran villages need to be followed up with a review of the spatial layout in the dwellings of other indigenous huta villages in the Mandailing Julu area. This is important to do, considering other villages in Mandailing Julu area have strong ties with Singengu village, especially the bonds of parkouman (fraternity) that are derived by the ancestors of the people surnamed Lubis. Further study is also interesting to follow up on the 
spatial layout of the Mandailing people in urban areas, to see the sustainability and sustainability of understanding bincar-bonom as the deep structure of the Mandailing people's residential spaces.

\section{ACKNOWLEDGMENT}

This research is part of the Indonesian government funded research, therefore the authors express deep gratitude to:

1. Directorate of Research and Community Service (DRPM) Ministry of Research and Technology of Higher Education (Kementristekdikti) who has provided research funding through Higher Research Grants of Higher Education (Penelitian Dasar Unggulan Perguruan Tinggi).

2. All of the people and the Hatobangan (old people) descendants of the king of Lubis in the Singengu and Habincaran villages who have provided important information needed during the research.

\section{REFERENCES}

Adiwijaya, D.R. (2011). Semiologi, Strukturalisme, Post-Strukturalisme, \& Kajian Desain Komunikasi Visual? Jurnal Humaniora, 2(1), pp. 803813.

Ahimsa-Putra, H.S. (2001). Strukturalisme LéviStrauss. Mitos dan Karya Sastra, Galang Press. Yogyakarta.

Ahimsa-Putra, H.S. (2014). Architecture as Language di Indonesia: Analisis Struktural Arsitektur Tradisional di Indonesia. Makalah Seminar. Disampaikan dalam seminar "Metodologi Penelitian Disertasi" diselenggarakan oleh Program Pascasarjana Universitas Parahiyangan dan Universitas Atma Jaya Yogyakarta. Universitas Atma Jaya Yogyakarta, 22 Mei 2014, Yogyakarta.

Hawkes, T. (2003). Structuralism and Semiotics. Routledge, Taylor \& Francis Group, London and New York.

Lakawa, A.R. (2015). The Relationship between Language and Architecture: A Case Study of Betawi Cultural Village at Setu Babakan, South Jakarta, Indonesia. International Journal of Humanities and Social Science, 5(8), pp. 84 101.
Lazutina T.V., Pupysheva I.N., Shcherbinin M.N., Baksheev V.N., and Patrakova G.V. (2016). Semiotic of Art : Language of Architecture as a Complex System of Signs. International Journal of Environmental \& Science Education, 11(17), pp. 9991-9998.

Marota, A., Spallone R., Turco M.L., Zich U., Vitali M., Marchis E. \& Pavignano M. (2017). Visual Images and Language in Architecture: Signifier Semiotics and Meaning Semiotics. Proceedings, I, 964; doi: 10.3390/proceedings1090964, Immagini MDPI, www.mdpi.com/journal/proceedings.

Nuraini, C. (2014a). Bincar-Bonom sebagai Basis Tata Ruang Permukiman Desa Singengu, Disertasi, Program Doktor, Fakultas Teknik Jurusan Teknik Arsitektur dan Perencanaan, Universitas Gadjah Mada, Yogyakarta.

Nuraini, C., Djunaedi, A., Sudaryono \& Subroto, T.Y.W. (2014b). Bincar-Bonom: The Basis of Spatial Arrangements of Singengu Village, Indonesia. ISVS Journal, Journal of the International Society for the Study of Vernacular Settlements, 3(2), pp. 1-16.

Nuraini, C. (2017). Room Arrangement of Vernacular Dwelling in Mandailing, Indonesia. International Journal of Engenering and Technology (IJET), 9(4), pp. 3427-3434.

Nuraini, C. (2017). Room Arrangement Concept: The Sacred-Profane of Heirloom Houses in Hutagodang Village, Mandailing, LivaS - International Journal on Livable Space, 2(2), pp. 4554.

Nurdiah, E.A., Asri, A. \& Hariyanto, A.D. (2015). Gendered Space in West Sumba Traditional Houses. Dimensi - Journal of Architecture and Built Environment, 42(2), pp. 69-76, DOI: 10.9744/dimensi.43.2.85-92, ISSN 0126-219X (print) / ISSN 2338-7858 (online)

Wicaksono, B., Siswanto, A., Kusdiwanggo, S. \& Anwar, W.F.F. (2016). Cultural Approach of Sustainability in Dwellings Culture Riparian Community Musi River Palembang. DimensiJournal of Architecture and Built Environment, 43(2), pp. 85-92, DOI: 10.9744/dimensi.4 3.2.85-92, ISSN 0126-219X (print) / ISSN 2338-7858 (online). 